\title{
Enhancing communication skills and ability to engage in life-long learning through effective assignment.
}

\author{
Shivanand P Prabhuswamimath ${ }^{1 *}$, I G Siddalingeshwar ${ }^{2}$, Veeresh Angadi ${ }^{3}$, Krishnaraja G Kodancha ${ }^{4}$, \\ Sanjay Kotabagi ${ }^{5}$
}

1, 2,3 Department of Automobile Engineering,

4, 5 Department of Mechanical Engineering

1shivanand@bvb.edu

2igs@bvb.edu

${ }^{3}$ veeresh@bvb.edu

${ }^{4}$ krishnaraja@bvb.edu

${ }^{5}$ sanjay_kotabagi@bvb.edu

\begin{abstract}
Communication is a purposeful activity of exchanging information and meaning across space and time using various technical or natural means. Communication requires a sender, a message, a medium and a recipient. Lifelong learning (LLL) is the "ongoing, voluntary, and self-motivated" pursuit of knowledge for either personal or professional reasons. Lifelong learning is being recognized by traditional colleges and universities as valid in addition to degree attainment. Proficiency in communication behaviors can make any engineer more versatile and thus more competitive in today's job market. Communication skills of engineers play a very important role in the era of globalization and competitiveness. Lifelong learning offers engineers the opportunity to bring up to date their knowledge of and enjoyment in the work they do which is very crucial for an organizational growth. Research paper and Case study analysis is a good opportunity to enhance Communication skills. Quiz and open book exam helps students in Lifelong Learning. One of the pedagogical ways to overcome this obscurity is effective assignment. An attempt made to enhance communication skills and lifelong learning in the course titled management theory and practice. The course mainly emphasis on Planning, Organizing, Leading, Controlling functions of management and Social Responsibility, Ethical guidelines for an organization. The students in a group took a case study and research paper pertaining to management concepts and their branch of study. This led to better learning process in the form of self directed learning and development of professional skills.
\end{abstract}

Shivanand P Prabhuswamimath ${ }^{1}$

${ }^{1}$ Department of Automobile Engineering

1'shivanand@bvb.edu
Keywords: Communication skills, Lifelong learning, Pedagogy, Assignment

\section{Introduction}

Industry leaders and educators are reassessing the preparedness of new graduates entering the organizations due to changes in the engineering profession [1].Strong communication skills (ABET 3g criteria)are a part of practically every interaction in engineering work and consistently ranks among the top three skills essential to the profession [2]. International projects are increasing, and cross-cultural communication and collaboration is rising in this era of globalization. Inadequate and ineffective communication skills reflect badly on the individual, the profession and serves to undermine the whole profile of the professional engineer. This in turn affects recruitment and retention in engineering [3]. Globalization and competitiveness have become the benchmark of any Multi National Company, and to cope up with this employee should to be equipped with good communication and soft skills. This clearly indicates engineering graduates require an ever increasing range of skills to maintain relevance with the global environment of the era [4]. Lifelong learning (ABET 3i criteria) is the continuous building of skills and knowledge throughout the life of an individual. In a lifelong learning model, people learn by doing individually, in groups, and from each other. Not only that they put learning into practice and reflect upon the learning. Meta cognitive or reflective skills that are critical to being an effective, self directed lifelong learner do not necessarily develop on their own. Instructors play a critical role in helping students develop the meta cognitive skills that they need to succeed not only in college but also all through life [5]. Lifelong Learning is critical for engaged citizens in the modern knowledge economy. The development of such generic or key competencies should be integrated 
throughout curricula, along with specific competencies in the disciplines such as engineering [6]. Management Education is dynamic in nature and need diverse information to handle different management problems. Management students should undergo in depth training to learn the management concepts. To understand the peculiar situations and to handle them effectively, case studies are widely used. The case study method helps the students in developing wisdom and gives lot of scope for application of knowledge [7].An attempt is made to address these issues by conducting Case Study Analysis, Research Paper Comphrension, Open Book Test and Quiz with clear objectives as follows:

\section{Objectives}

- To enhance Communication skills and Lifelong learning;

- To improve the learning process through the real time methods, that enable students to understand the utilization of theory for practice;

- To explain the importance of management functions which plays a major role in the upliftment of an organisation;

- To learn and develop professional skills - to work in a team, to collect necessary technical information and present a PowerPoint presentation.

\section{Methodology}

Final year students study management theory and practice course. The class strength is 70 for the academic year 201415.In conventional way of writing assignment students reproduce the textbook matter which limits the scope of learning, thereby reducing the ability to think beyond the curriculum. Evaluation scheme also plays a vital role in educational institutions, which is not fully addressed in conventional assignment writing system. In the present methodology students write individual assignment (Quiz, Open Book Examination) in classroom and work in a group with the following planned activities.

1. Formation of group.

2. Selection of case study and Research Paper.

3. Correlating the functions of management in analysing the Case and Research Paper.

4. Analysing the methodology used in Research paper and correlating to their branch of study.

5. Preparation of PowerPoint Presentation in a prescribed format and style.

6. Presentation with constraints.

\begin{tabular}{|c|c|c|c|c|}
\hline $\begin{array}{l}S \\
\text { No }\end{array}$ & Activity & Marks & Time & $\begin{array}{l}\text { Individual/ } \\
\text { Group }\end{array}$ \\
\hline 1 & 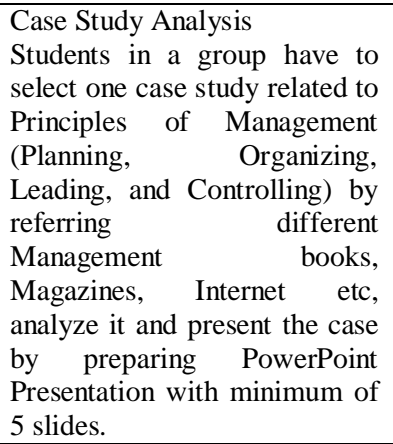 & 05 & $\begin{array}{l}10 \\
\text { Min }\end{array}$ & Group \\
\hline 2 & $\begin{array}{l}\text { Research Paper Comphrension } \\
\text { Identify a research paper by } \\
\text { referring e-Jounals, Books,etc } \\
\text { which relates management } \\
\text { concepts (Planning, } \\
\text { Organizing, Leading, and } \\
\text { Controlling) with Information } \\
\text { technology and their branch of } \\
\text { study. } \\
\text { Prepare PowerPoint } \\
\text { Presentation of minimum 5 } \\
\text { slides to present the identified } \\
\text { research paper. }\end{array}$ & 05 & $\begin{array}{l}10 \\
\text { Min }\end{array}$ & Group \\
\hline 3 & $\begin{array}{l}\text { Open Book Test } \\
\text { Questions will be asked from } \\
\text { Principles of Management } \\
\text { (Planning, Organizing, } \\
\text { Leading, and Controlling from } \\
\text { the syllabus). Student has } \\
\text { flexibility to use any } \\
\text { management book, notes to } \\
\text { write the exam. }\end{array}$ & 05 & $\begin{array}{l}60 \\
\text { Min }\end{array}$ & Individual \\
\hline 4 & $\begin{array}{l}\text { Quiz } \\
20 \text { multiple choice questions } \\
\text { will be given on Principles of } \\
\text { Management. (Planning, } \\
\text { Organizing, Leading, and } \\
\text { Controlling). } \\
\text { Mode : Moodle } \\
\text { Software/Manual Method }\end{array}$ & 05 & $\begin{array}{l}30 \\
\text { Min }\end{array}$ & Individual \\
\hline
\end{tabular}

\section{Results and Discussions}

A questionnaire was designed that involved a set of criteria to measure the effectiveness of Effective Assignment and the same was circulated to students to receive their feedback about the process (new methodology used for assignment component).The questionnaire and weightage are shown in table 1 . This survey is intended to measure the effectiveness of EA on "teaching \& learning" process in BVBCET. The collected feedback was analysed and percentage of distribution perception is plotted (Fig 1.1a and b). Students marks scored in each of assignment components are plotted (Fig 1.2a and b). 
[Based on your personal experience, kindly give your valuable feedback by ticking $(\sqrt{ })$ in the relevant box $(\square)$ on Likert five-point scale].

\begin{tabular}{|c|c|c|c|c|c|c|}
\hline Sl.No & CRITERIA & & 4 & 3 & & \\
\hline 1 & $\begin{array}{l}\text { Case study analysis paves } \\
\text { way for developing wisdom } \\
\text { and gives lot of scope for } \\
\text { application of knowledge } \\
\text { and helps in adding value to } \\
\text { text book teaching. }\end{array}$ & $\square$ & $\square$ & $\square$ & & $\square$ \\
\hline 2 & $\begin{array}{l}\text { The Research Paper } \\
\text { Comphrension enhances } \\
\text { lifelong learning skills. }\end{array}$ & $\square$ & $\square$ & $\square$ & & $\square$ \\
\hline 3 & $\begin{array}{l}\text { Open Book Examinations } \\
\text { helped in enhancing thinking } \\
\text { skills and processing } \\
\text { information ( skills of } \\
\text { acquiring, modifying and } \\
\text { creating knowledge) }\end{array}$ & $\square$ & $\square$ & $\square$ & & $\square$ \\
\hline 4 & $\begin{array}{l}\text { Quizzes helps in boosting } \\
\text { our memories and recalling } \\
\text { power. }\end{array}$ & $\square$ & $\square$ & $\square$ & & $\square$ \\
\hline 5 & $\begin{array}{l}\text { The EA has positive impact } \\
\text { on learning of the course }\end{array}$ & $\square$ & $\square$ & & & $\square$ \\
\hline
\end{tabular}

Any other comments:

\begin{tabular}{|l|l|l|}
\hline Name (Optional) & Program & Semester \\
\hline & & \\
\hline
\end{tabular}

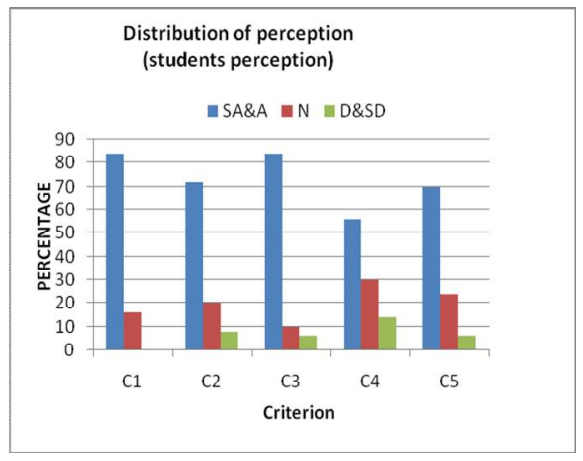

Figure 1.1(a): Bar charts showing the percentage Student's distribution of perception

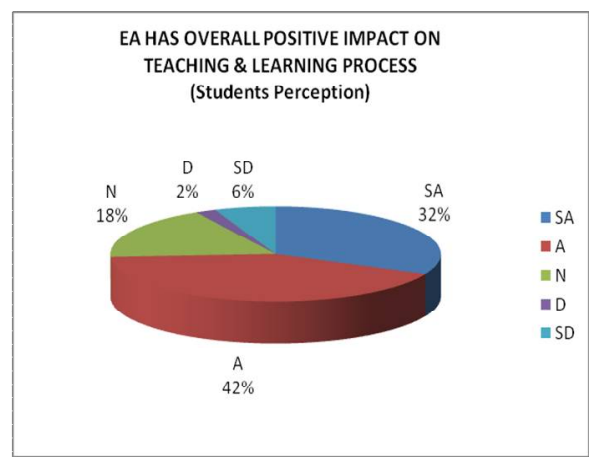

Figure 1.1(b): Pie chart showing the percentage of perception taking all criteria into consideration

\begin{tabular}{|l|c|c|c|c|c|}
\hline SUM & 246 & 246 & 244 & 247 & 247 \\
\hline AVERAGE & 4.92 & 4.92 & 4.88 & 4.94 & 4.94 \\
\hline SD & 0.27 & 0.27 & 0.38 & 0.23 & 0.31 \\
\hline CV & 0.05 & 0.05 & 0.07 & 0.04 & 0.06 \\
\hline $\begin{array}{l}\text { 5(Strongly } \\
\text { Agree) }\end{array}$ & 46 & 46 & 45 & 47 & 48 \\
\hline $\begin{array}{l}\text { 4(Agree) } \\
\text { 3(neutral) }\end{array}$ & 4 & 4 & 4 & 3 & 1 \\
\hline $\begin{array}{l}\text { 2(disagree) } \\
\text { 1(strongly } \\
\text { disagree) }\end{array}$ & 0 & 0 & 1 & 0 & 1 \\
\hline & 0 & 0 & 0 & 0 \\
\hline $\begin{array}{l}\text { \% of (SA } \\
\text { \& A) }\end{array}$ & 100 & 100 & 98 & 100 & 98 \\
\hline $\begin{array}{l}\text { \% of } \\
\text { Neutral }\end{array}$ & 0 & 0 & 2 & 0 & 2 \\
\hline $\begin{array}{l}\text { \% of } \\
\text { (D\&SD) }\end{array}$ & 0 & 0 & 0 & 0 & 0 \\
\hline
\end{tabular}

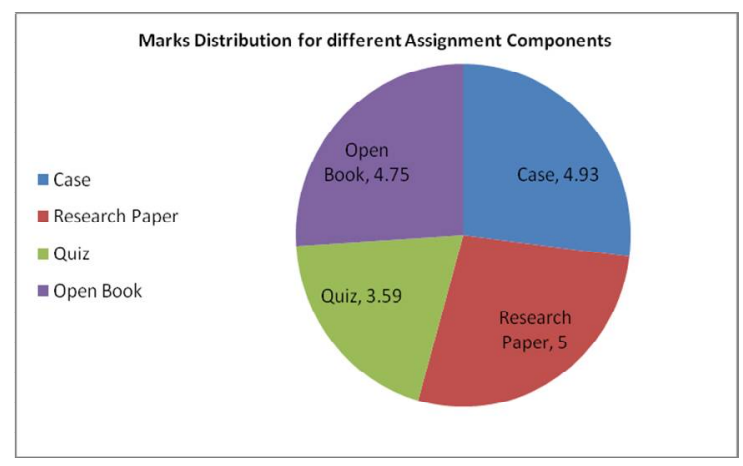

Figure 1.2(a): Bar charts showing the Marks Distribution for Assignment Components 


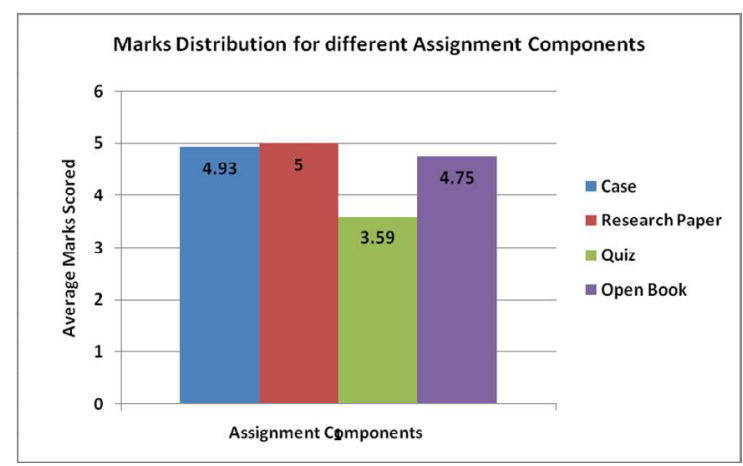

Figure 1.2(b): Pie chart showing the

Marks Distribution for Assignment Components

\section{Evidences and Experiences}

An effort is also made to collect comments from students, which can be used to for improvement in forthcoming semester. The following figure (1.3 a) presents the snapshot of feedback given by students.
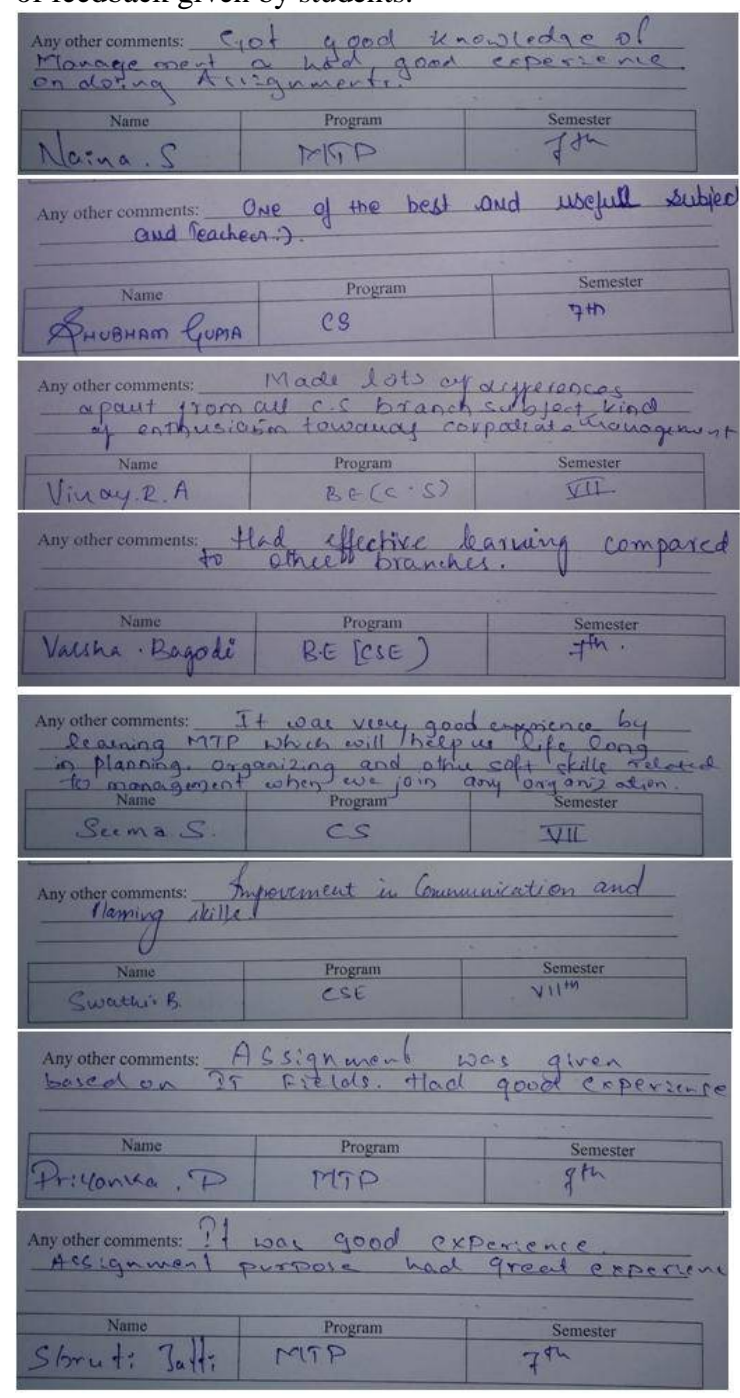

Figure 1.3(a): Snapshot of feedback given by students

\section{Conclusions}

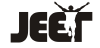

- It has been observed that Effective assignment work resulted in relatively better learning process by the students.

- Outcome 3g (communicate effectively) and Outcome $3 \mathrm{i}$ (recognize need for and be able to engage in lifelong learning) addressed through effective assignment.

- It has been also observed that average scoring for all assignment components is more than $70 \%$, highest being $100 \%$ for Research Paper Analysis activity.( Figure 1.4(a))

- Research Paper and Case study components were group activity and students performed well in group activity than individual assignments. ( Figure 1.4(a) )

- This extended tangible benefits like practical exposure to students, enhanced creative thinking about the subject and many intangible benefits like professional skills improve the student's ability to work in a team, communication skills, lifelong learning ability, making students to start preparing for their career at an early stage.

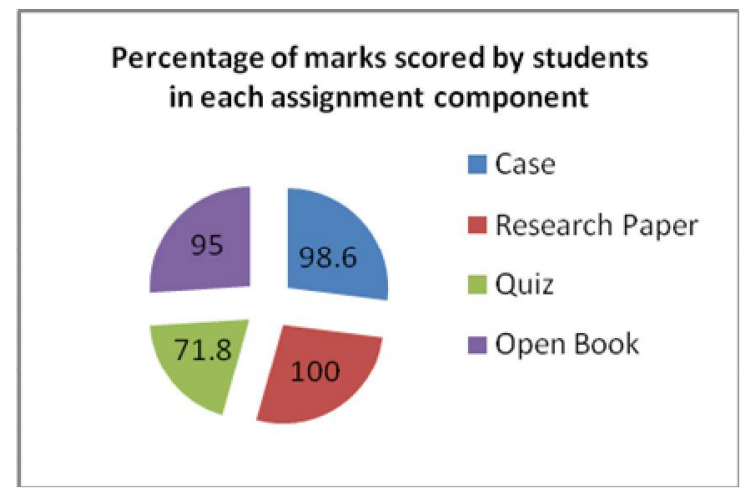

Figure 1.4(a): Percentage of marks scored by students in each assignment component

\section{ACKNOWLEDGEMENTS}

The authors wish to thank Dr. Ashok Shettar, Principal BVBCET, Hubli for giving an opportunity to implement new pedagogical tool in the curriculum. The author also extends gratitude to their colleagues Prof. TVM Swamy, Dr R G Mench, Dr Anil Badiger, Dr Sanjay Kotabagi, Dr. S.B. Burli and Prof Nagaraj Ekbote for their unwavering towards successful accomplishment of the task and students.

\section{REFERENCES}

1. Communication and the Engineering Profession: A Field Study by Myra L. Corrello, Ph.D. Candidate, UK

College of Communication

2. Vital Skills in Engineering: Communication, by Christine Nicometo, Kevin J. B. Anderson, Sandy Courter, Thomas McGlamery, and Traci Nathans Kelly 
3. Communication Skills for the 21st Century Engineer Marc J. Riemer UNESCO International Centre for Engineering Education (UICEE) Faculty of Engineering, Monash University, Clayton, Melbourne, VIC 3800, Australia

4. Communication Skills for Engineers in Global Arena Shikha Seetha Department of Humanities, VNS Institute of Technology, Bhopal, (MP)

5. Lifelong Learning by Sandra Courter, Kevin J. B. Anderson, Thomas McGlamery, Traci Nathans Kelly and Christine Nicometo

6. Lifelong Learning Competencies Program for Engineers, CATALINA MARTI'NEZ- MEDIANO, Department of Research Methods and Diagnosis in Education I, Spanish University for Distance Education, Madrid, Spain.E-mail: cmarme@edu.uned.es

7. Case Study Method of Teaching in Management Education Dr .Suresh Reddy Jakka, Assistant Professor, Department of Business Management, Mahatma Gandhi University, Nalgonda, Andhrapradesh, India, Sita Ramanjaneyulu Mantha, Head \& Associate Professor, Department of Business Management, Adarsh G.College of Comp. Sciences, Mahabubnagar, Andhrapradesh, India

\section{ABBREVIATIONS}

LLL-Lifelong Learning

EA-Effective Assignment

SA-Strongly Agree

A- Agree

N-Neutral

D-Disagree

SD-Strongly Disagree 